\title{
KECEMBURUAN DAERAH PENGHASIL SETELAH PRAKTEK
}

\section{DESENTRALISASI ASIMETRIS}

\author{
Muhammad Habibi \\ Magister Ilmu Pemerintahan \\ Universitas Muhammadiyah Yogyakarta \\ habibi.id@gmail.com
}

\author{
Erni Zuhriyati \\ Dosen Magister Ilmu Pemerintahan \\ Universitas Muhammadiyah Yogyakarta \\ ernizuhriyati@yahoo.com
}

\section{Pendahuluan}

Menyusul diperolehnya otonomi khusus bagi dua provinsi paling barat dan paling timur Indonesia, yaitu Aceh dan Papua, sejumlah daerah di Indonesia mulai mewacanakan untuk mengajukan tuntutan serupa. Beberapa daerah, seperti Bali, mengajukan tuntutan kekhususan karena alasan budaya, di samping tuntutan pembagian hasil pariwisata yang lebih besar, sementara beberapa daerah lain meminta otonomi khusus karena latar belakang ekonomi. Daerah-daerah yang menuntut otonomi khusus karena alasan ekonomi, umumnya merupakan daerahdaerah yang selama ini memiliki sumber daya alam yang kaya. Mereka menilai bahwa kontribusi mereka terhadap perekonomian nasional amatlah besar, namun tidak sebanding dengan yang kembali ke daerah tersebut.

Secara khusus daerah-daerah yang memiliki sumber daya alam (SDA) yang kaya seperti Riau, Kalimantan Timur (Kaltim), Kalimantan Tengah (Kalteng), menyaksikan bahwa kekayaan sumber daya alam selama ini tidak mampu mensejahterakan masyarakat setempat, sebaliknya mereka memandang sungguh ironis bagaimana tingkat kesejahteraan rakyat setempat jauh berada di bawah daerah-daerah yang tidak memiliki SDA yang kaya. Eksploitasi besar-besaran terhadap kekayaan alam setempat oleh pemerintah pusat telah menimbulkan kerusakan alam yang luar biasa bagi daerah.

Provinsi Kaltim merupakan salah satu daerah yang merasakan ketidakadilan tersebut. Keluhan utama ialah menyangkut tertinggalnya pembangunan infrastruktur di Kaltim. Jangankan dibandingkan dengan di Pulau Jawa, banyak kalangan di Kaltim sering menatap dengan penuh keheranan bagaimana mungkin infrastruktur di Kaltim jauh lebih buruk dibanding tetangga mereka Kalimantan Selatan misalnya, padahal dari segi kekayaan SDA, Kaltim jauh lebih besar.

Kaltim juga memandang dengan keheranan bagaimana mungkin daerahdaerah yang pernah bergejolak seperti Aceh dan Papua justru menikmati otonomi khusus (otsus), sementara daerah “yang patuh" seperti Kaltim justru tidak mendapat perhatian pemerintah pusat. Ini membuktikan bahwa pendekatan politik jauh lebih mendominasi dalam pemberian otonomi khusus dibandingkan dengan pendekatan ekonomi, padahal semestinya dalam pemberian otonomi khusus juga memperhatikan pertimbangan ekonomi.

Tulisan ini mengkaji latar belakang lahirnya tuntutan otsus Kaltim, proses pengajuan tuntutan tersebut, serta analisis mengenai rasionalitas (kekuatan dan kelemahan) tuntutan Otsus Kaltim. 


\section{Desentralisasi Asimetris dan Kapasitas Daerah}

Dewasa ini ada kecenderungan semakin banyak negara bergerak untuk mengadopsi sistem desentralisasi yang lebih luas, dengan menyerahkan otoritas pemerintahan secara signifikan dari pusat ke tingkat yang lebih rendah. Cara tersebut diyakini merupakan sarana untuk memberikan kelompok-kelompok etnis dan regional yang berbeda untuk menjalankan dan mengontrol urusan mereka sendiri secara otonom. Jika daerah memiliki otonomi dalam hal kemampuan untuk menentukan urusan lokal mereka sendiri, maka diasumsikan akan membuat mereka merasa lebih nyaman, dan yang pada gilirannya lebih bersedia untuk menerima otoritas dan legitimasi yang lebih besar dari negara nasional. Bentuk-bentuk desentralisasi dengan demikian dapat memperkuat demokrasi dan meningkatkan stabilitas.

Penggolongan desentrasi sendiri bermacam-macam. Ada ahli yang membagi desentralisasi menjadi tiga, yakni dekonsentrasi atau desentralisasi administrasi, desentralisasi fiskal, dan desentralisasi demokratik (Manor 1999: 5). Kathleen O’Neill memperkenalkan konsep desentralisasi efektif, yaitu desentralisasi politik dan desentralisasi fiskal secara bersama-sama dalam arti pelimpahan kekuasaan politik dan fiskal ke pemerintahan bawahan (O’Neil 2005: 17)

Sesungguhnya selain desentralisasi teritorial juga dikenal adanya desentralisasi fungsional dan desentralisasi administratif. Desentralisasi fungsional adalah pelimpahan sebagian fungsi pemerintahan kepada organ atau badan asli yang khusus dibentuk untuk itu. Sedangkan, desentralisasi administratif adalah pelimpahan wewenang yang semula dipusatkan pada penguasa kepada pejabatpejabat di bawahnya. Desentralisasi administratif dapat dianggap sebagai modifikasi atau penghalusan dari sentralisasi (Koswara 2001: 20). Selanjutnya, dikenal pula dengan apa yang disebut desentralisasi kebudayaan, yakni pemberian hak kepada golongan-golongan dalam masyarakat untuk menyelenggarakan kebudayaan sendiri (Bahar 2007: 56).

Desentralisasi diyakini akan membuat pemerintah menjadi lebih dekat dan lebih responsif terhadap kebutuhan-kebutuhan rakyat. Ketika pemerintah lebih dekat dengan rakyat, akan lebih mungkin untuk dimintai pertanggungjawaban oleh mereka untuk keberhasilan dan kegagalan dalam penyediaan pelayanan dasar, pemeliharaan ketertiban, dan resolusi yang adil atas isu-isu lokal termasuk ketika terjadi perselisihan. Setiap fungsi pemerintahan harus dilakukan oleh tingkat pemerintahan yang mampu melakukan fungsi yang efektif (Diamond 2004).

Akan tetapi, perlu disadari juga bahwa desentralisasi juga kadang membawa risiko bagi demokrasi. Di banyak negara, pemerintah di tingkat provinsi atau kabupaten justru didominasi oleh bos politik yang tidak bermain dengan aturan demokratis atau menghormati hak-hak warga negara. Pemimpin lokal dapat saja mengintimidasi oposisi. Untuk mengatasinya, tetap harus ada konstitusi nasional atau sistem peradilan nasional, di mana penegak hukum di tingkat nasional memiliki kewenangan untuk menyelidiki penyalahgunaan kekuasaan, pelanggaran hak-hak, dan tuduhan korupsi dalam pemerintah di tingkat provinsi atau kabupaten.

Kendati telah direvisi melalui UU 23/2014 Indonesia pernah memberlakukan UU 32/2004 dan UU No. 22/1999 yang sedikit banyak telah 
terpengaruh oleh sistem federal. Ini agaknya sejalan dengan Konstitusi kita hasil amandemen pada Pasal 18 yang juga menyebutkan bahwa pemerintahan daerah menjalankan otonomi seluas-luasnya, kecuali urusan pemerintahan yang oleh undang-undang ditentukan sebagai urusan Pemerintahan Pusat; klausul yang memberi kesan pengaruh dari pemikiran federal tersebut. Pelaksanaan otonomi daerah di Indonesia tak pelak telah membawa konsekwensi pada adanya pembagian kewenangan antara pemerintah pusat dan pemerintah daerah. Hampir seluruh kewenangan pemerintah pusat diserahkan kepada daerah, kecuali bidang politik luar negeri, pertahanan keamanan, yustisi, moneter dan fiskal nasional, serta agama. Hal ini menimbulkan peningkatan tanggung jawab pemerintahan di daerah yang sangat besar, termasuk bagi daerah dengan status otonomi khusus.

Otonomi daerah dalam organisasi negara kesatuan sesungguhnya lebih terbatas dibandingkan negara bagian di negara federal (Hoessein 2011: 26). Sebagai negara kesatuan (unitary), model hubungan antartingkat pemerintahan menganut pembagian kewenangan di setiap level pemerintahan yang disertai dengan pengawasan yang berjenjang. Pada umumnya pemerintahan subnasional bertindak atas nama pemerintah pusat, (sebagaimana ditulis oleh Shah \& Shah 2006). Kewenangan provinsi tidak lebih banyak/strategis dari kewenangan nasional maupun pemerintahan lokal (kabupaten/kota), sebagaimana terlihat dalam posisi state di negara federal pada umumnya. Paling tidak ada tiga ciri hubungan antar tingkat pemerintahan di negara-negara kesatuan. Pertama, pengembangan kebijakan dan standar pelayanan ditentukan oleh pemerintah di level nasional. Kedua, pengawasan implementasi dilakukan oleh state atau tingkat propinsi. Ketiga, pelayanan publik langsung diberikan oleh pemerintah lokal.

Memasuki era reformasi, sejumlah daerah bergairah untuk menuntut otonomi dan desentralisasi yang lebih luas. Pemerintah jelas punya tanggung jawab untuk merespon kepentingan dan kapasitas daerah yang beragam. Kesalahannya seringkali berada pada pemberian kewenangan yang sifatnya seragam antara satu daerah dengan daerah lain, sebagaimana kita lihat dewasa ini, di mana itu berangkat dari asumsi yang salah bahwa kapasitas administrasi lokal itu seragam. Tentu saja tidak logis memberi jumlah kewenangan yang sama antara satu daerah yang telah lebih maju kepasitas lokalnya dibandingkan dengan daerah lain yang mungkin masih belum baik. Di sinilah sebenarnya esensi pemberlakuan desentralisasi asimetris, yakni memberikan kewenangan atau urusan yang sifatnya tidak seragam antara satu daerah dengan daerah lain. Otonomi khusus adalah merupakan salah satu bentuk atau varian lain dari desentralisasi asimetris tersebut, akan tetapi selama ini pemberlakuannya dikritik terlalu mengedepankan pendekatan politik ketimbang pendekatan ekonomi.

Selama ini negara kesatuan memiliki tantangan yang besar karena cenderung mengatur desentralisasi secara simetris. Karena pengaturan simetris, ketidakpuasan lokal cenderung besar. Dalam konteks perbedaan wilayah dan etnis, desentralisasi dapat memicu perpecahan bangsa jika tidak diatur dengan tepat. Negara yang terbelah atau terdisintegrasi lebih disebabkan oleh tidak terbiasanya mengembangkan cara-cara demokratis dalam kerangka devolusi kekuasaan. Padahal, devolusi sangat penting untuk menyatukan kelompok-kelompok yang 
diawali dalam suatu lokalitas yang asli (otentik), dengan sifat sukarela (volunter atau tidak dipaksa), dan dengan persatuan politik yang absah (Tryatmoko 2013: 9).

Tuntutan otonomi yang lebih besar dan termasuk otonomi khusus juga berasal dari kenyataan bahwa pemerintah pusat memberikan bagian yang terlalu kecil kepada daerah dalam kerangka dana perimbangan, jumlah mana dianggap tidak sebanding dengan kekayaan alam atau kontribusi yang diberikan oleh daerah bersangkutan kepada pusat. Sedari masa Orde Baru dan hingga pasca Orde Baru memang kita menyaksikan kenyataan masih terbatasnya wewenang daerah otonom dalam bidang keuangan. Terbatasnya wewenang ini dimanifestasikan dalam kontribusi Pendapatan Asli Daerah (PAD) yang sangat kecil terhadap APBD. Tentu saja apabila pemerintah pusat tidak menutup kekurangan anggaran, daerah tidak akan banyak melakukan aktivitas. Selama ini pemerintah pusat tampaknya lebih suka menyediakan dana untuk menutupi anggaran daripada memberikan wewenang kepada daerah otonom untuk menggali sumber-sumber keuangannya sendiri. Pemberian dana semacam ini akan mengurangi beban, tetapi meningkatkan ketergantungan daerah kepada pusat (Hoessein 2011: 14-15).

Diskusi mengenai capacity constraints tidak tepat mengasumsikan bahwa semua pemerintahan subnasional adalah sama. Dalam kenyatannya, pemerintahan kota, terutama di kota-kota besar, memiliki kapasitas yang lebih besar untuk mengatur keuangan pelayanan publik daripada yang dilakukan pemerintahan desa. Dengan kata lain, pemerintahan daerah yang berbeda - provinsi, kabupaten, dan kota - memiliki perbedaan kapasitas pendanaan dan manajemen. Tentu hal penting di sini adalah pemerintahan lokal seharusnya tidak dibebani dengan kewajiban untuk menjalankan fungsi dan menyediakan pelayanan, sementara mereka tidak memiliki sumber-sumber pendapatan dan kapasitas untuk melaksanakannya. Oleh sebab itu penting untuk mempertimbangkan pemberian desentralisasi yang tidak sama di antara daerah. Prinsip inilah yang sering terdengar sebagai desentralisasi asimetris. Dalam konteks ini, prinsip asymmetric decentralization menawarkan suatu pendekatan untuk mendesentralisasikan pertanggungjawaban yang lebih feasible daripada mendasarkan pada pendekatan lainnya termasuk penyeragaman. Akan tetapi permasalahannya sebenarnya bukan hanya merujuk pada persoalan kapasitas pemerintah daerah, melainkan juga persoalan kapasitas pemerintah nasional, yakni seberapa kapasitas pemerintah pusat dan daerah dalam mendukung dan mengatur urusan yang terdesentralisasi. Selain itu, perlu dilihat kapasitas politik untuk mengidentifikasi dan merespons preferensi hingga ke tingkat individu. Kapasitas politik dalam konteks ini tentu berkaitan dengan saluran-saluran partisipasi lokal yang multisektoral, baik itu ekonomi, politik, sosial, budaya, dan lain sebagainya (Litvak et al. 1998: 28).

Akan tetapi, terhadap maraknya tuntutan otonomi khusus tentu kita memerlukan sejumlah indikator yang dapat digunakan untuk dapat menilai tingkat rasionalitas tuntutan otonomi khusus suatu daerah. Indikator pertama yang penting ialah apakah tuntutan tersebut merupakan sesuatu yang muncul secara alami dari pelbagai eksponen masyarakat di daerah tersebut; ataukah justru bukan sebaliknya, yakni hanya merupakan suara segelintir elite, yang mana tidak sepi dari kepentingan-kepentingan tertentu. 
Ada juga masalah kapasitas pemerintahan di tingkat lokal dan propinsi. Ini bisa menjadi masalah tertentu dalam hal kemampuan untuk meningkatkan, anggaran, dan menghabiskan sumber daya. Sebagaimana dikatakan oleh Diamond (2004), bahwa pemerintah daerah dituntut untuk mengembangkan kapasitas untuk mengelola pendapatan dan memberikan layanan yang diperlukan. Seringkali, ini membutuhkan periode pelatihan dan tahapantahapan tertentu sebelum tanggung jawab didelegasikan turun dari pusat. Satu hal penting di dalam kelancaran desentralisasi dan otonomi daerah adalah perlunya memperhatikan masalah kapasitas pemerintahan lokal, baik lembaga eksekutif maupun lembaga legislatif. Kapasitas yang dimaksud adalah kemampuan dalam hal meningkatkan, menganggarkan, dan membelanjakan sumber daya lokal, tidak hanya dilihat dari kemampuan manajerial birokrasi pemerintahan lokal, tetapi juga terkait dengan keputusan politik lembaga perwakilan daerah.

Faktor yang tidak kalah pentingnya ialah kemampuan administrasi daerah bersangkutan. Kemampuan administrasi di sini ialah kemampuan birokrasi untuk melaksanakan kebijakan secara efisien dan efektif. Dengan demikian itu berarti kemampuan administrasi dalam melaksanakan kebijakan daerah (Riggs 1969). Dalam tulisan ini, efisiensi sebagai rasio antara output dan input diukur dari sejauh mana daerah mampu mengelola anggaran pembangunan sesuai harapan. Sementara itu, efektivitas dilihat dari sejauh mana daerah mampu memanfaatkan dana pembangunan yang selama ini secara baik dan maksimal, yang tercermin dari penggunaan anggaran pembangunan secara maksimal.

\section{Latar Belakang Tuntutan Otsus}

Ketidakadilan pembangunan merupakan isu utama yang melatarbelakangi tuntutan otonomi khusus Kaltim. Sebagai daerah yang memiliki kekayaan sumber daya alam dan memberi kontribusi yang besar bagi perekonomian nasional, namun pembangunan di wilayah Kaltim masih tertinggal akibat kurang diperhatikan oleh pemerintah pusat.

Sebagai daerah penyumbang devisa terbesar di Indonesia tentu sudah selayaknya jika pembangunan di Kaltim harus menjadi prioritas, terutama di daerah pedalaman dan perbatasan. Hingga dewasa ini, Kaltim belum merasakan manfaat yang adil akan pengelolaan sumber daya alam (SDA) dan juga belum merasakan kesejahteraan yang proporsional baik di kota, pedalaman, dan perbatasan (http://www.scribd.com, 20 Agustus 2010). Padahal, di sisi lain Kaltim merupakan provinsi penyumbang PDRB (Produk Domestik Regional Bruto) yang besar dari sektor Pertambangan Minyak Bumi.

Kaltim membandingkan dengan pembagian dana bagi hasil (DBH) berdasarkan Undang-undang Nomor 21 Tahun 2001 tentang Otonomi Khusus Papua, di mana pembagian pertambangan minyak bumi menggunakan pola 70 persen untuk daerah dan 30 persen untuk pemerintah pusat. Begitu pula pada Undang-undang Nomor 11 Tahun 2006 tentang Pemerintahan Aceh, di mana Aceh menikmati bagi hasil 70 persen dari pendapatan kekayaan alamnya. Orang Kaltim mungkin menatap dengan keheranan, bahwa daerah-daerah yang pernah bergejolak seperti Aceh dan Papua justru mendapat bagi hasil yang besar, sementara Kaltim yang merupakan "anak manis dan penurut" malah ditekan. Sehingga timbul 
pemikiran, apakah Kaltim harus menjadi anak nakal terlebih dahulu yakni memberontak seperti Aceh, baru kemudian akan mendapat bagi hasil yang besar seperti Aceh (Wawancara dengan Kabid Migas Dinas Pertambangan Kaltim, Puji, 14 Mei 2013, di Samarinda).

Kaltim tentu menyadari betul posisinya sebagai salah satu dari empat provinsi terkaya sumber daya alamnya di Indonesia di samping Aceh, Riau,dan Papua. Bahkan Kaltim meyakini bahwa potensi sumber daya alam mereka lebih lengkap. Oleh sebab itu, Kaltim merasa berhak mendapat keistimewaan berupa dana bagi hasil yang lebih besar atau minimal sama dengan yang diberlakukan di Papua dan Aceh. Kaltim mengetahui pula bahwa Aceh dan Papua menikmati Otsus lantaran adanya faktor separatis di kedua daerah tersebut, sementara Kaltim tidak lantaran bukan wilayah semacam itu.

Bagi orang Kaltim masalah ketidakmerataan dan ketidakadilan dalam pembagian hasil pembangunan terlihat jelas dari klausul yang diatur dalam UU No.33/2004 tentang Perimbangan Keuangan Pusat dan Daerah. Dalam pasal 14 huruf e undang-undang tersebut mengatur penerimaan pertambangan minyak bumi yang dihasilkan dari wilayah penghasil, setelah dikurangi komponen pajak dan pungutan lainnya sesuai peraturan perundang-undangan, kemudian dibagi dengan perimbangan 84,5 persen untuk pemerintah dan 15,5 persen untuk daerah. Kemudian pada pasal 14 huruf $\mathrm{f}$, mengatur penerimaan pertambangan gas bumi yang dihasilkan dari daerah penghasil, setelah dikurangi komponen pajak dan pungutan lainnya sesuai peraturan, kemudian dibagi dengan perimbangan 69,5 persen untuk pemerintah dan 30,05 persen untuk daerah. Dari pembagian itu dinilai tidak adil, karena seharusnya penerimaan minyak bumi untuk Kaltim dapat ditingkatkan lagi beberapa persen, bukan 15,5 persen seperti yang sudah berlaku selama ini.

Ketidakadilan tersebut mendorong masyarakat Kaltim, yang diprakarsai oleh kelompok yang menamakan diri Majelis Rakyat Kaltim Bersatu (MRKTB), untuk melakukan upaya judicial review (JR) atau uji materiil yang diajukan ke Mahkamah Konstitusi (MK) atas Pasal 14 huruf (e) dan (f) tersebut. Mereka menggugat pasal yang berbunyi: "Penerimaan pertambangan minyak bumi yang dihasilkan dari wilayah daerah yang bersangkutan setelah dikurangi komponen pajak dan pungutan lainnya sesuai dengan peraturan perundangundangan, dibagi dengan imbangan 84,5\% (delapan puluh empat setengah persen) untuk Pemerintah; dan 15,5\% (lima belas setengah persen) untuk daerah."

Gubernur Kaltim, Awang Faroek, secara resmi menerima audiensi MRKTB dan turut hadir dalam sidang-sidang JR di MK sebagai bentuk dukungan terhadap perjuangan JR oleh MTKTB. Tidak mengherankan bila kalangan pemerintahan daerah setempat baik itu Pemprov Kaltim maupun pemerintah-pemerintah kabupaten memberi dukungan termasuk pendanaan terhadap upaya JR, karena Pemprov Kaltim khususnya tentu diuntungkan bila tuntutan tersebut berhasil. Sementara terhadap tuntutan otsus, pihak Pemprov Kaltim dinilai bersikap "malumalu kucing", karena masih merasa segan terhadap pemerintah pusat (wawancara dengan Pemred Kaltim Post, Rizal Juraid, 13 Mei 2013, di Samarinda). Belakangan uji materi tersebut kandas di MK, sehingga memicu munculnya gagasan dari sementara pihak di Kaltim yang merasa sudah hilang kesabarannya untuk menuntut 
otonomi khusus Kaltim, dan bahkan Kaltim merdeka apabila otsus Kaltim tidak dipenuhi oleh pemerintah pusat.

Di luar Kaltim, tuntutan otsus sendiri sebenarnya merupakan wacana yang belakangan cukup lantang disuarakan oleh daerah-daerah di Kalimantan. Kaukus DPD dan DPR RI asal empat provinsi di Kalimantan pernah mendesak pemerintah pusat menetapkan otonomi khusus bagi empat provinsi di Kalimantan. Ketidakadilan pembangunan dan minimnya kontribusi pemerintah pusat kepada daerah, melatarbelakangi tuntutan status otonomi khusus seperti Aceh dan Papua (http://www.portalkbr.com, 26 Desember 2012). Tuntutan otonomi khusus didasarkan pada kontribusi empat provinsi di Kalimantan bagi APBN yang mencapai dua pertiga atau lebih dari Rp900 triliun dari hasil sumber daya alam berupa hasil tambang batubara, minyak, gas dan mineral lainnya. Sementara itu, kontribusi yang diberikan pemerintah pusat berupa dana royalti terbilang sangat kecil.

Desakan pemberian otonomi khusus Kalimantan juga disuarakan oleh Forum Peduli Banua (FPB) pada musyawarah masyarakat Kalimantan yang digelar tahun 2012. Tuntutan ini muncul lantaran menilai ada ketidakadilan dalam pembangunan di Pulau Kalimantan, misalnya terkait krisis listrik berupa aliran listrik sering padam bergiliran di hampir seluruh wilayah yang sempat menimpa provinsi-provinsi di Pulau Kalimantan. FPB menginginkan langkah-langkah dialogis dengan pemerintah pusat, seperti membahas kembali opsi pembangunan di Kalimantan. Tapi bila langkah-langkah dialog tidak mendapatkan perhatian, FPB bertekan untuk melakukan gugatan bersama guna mendapatkan otonomi khusus wilayah di Kalimantan.

Jauh sebelumnya, pada 29 Mei 2008, Rapat Kerja Nasional I Majelis Adat Dayak Nasional (MADN) yang berlangsung di Palangka Raya telah mendeklarasikan sembilan tuntutan kepada pemerintah pusat, di antaranya berupa tuntutan agar pemerintah pusat memberikan otonomi khusus kepada wilayah kawasan Kalimantan, yang meliputi Provinsi Kalimantan Tengah, Kalimantan Timur, Kalimantan Barat, dan Kalimantan Selatan. Permintaan otonomi khusus tersebut erat kaitannya dengan pembangunan perbatasan di dua provinsi, yakni Kalbar dan Kaltim, yang selama ini terkesan terbelakang. Pemerintah provinsi atau daerah tidak bisa berbuat apa-apa dengan kawasan perbatasan, karena kewenangannya ada di tangan pemerintah pusat.

Otonomi khusus juga layak diterima masyarakat kawasan Kalimantan, mengingat kawasan ini termasuk daerah tertinggal di Indonesia, kecuali Kaltim. Padahal keempat provinsi kawasan Kalimantan ini merupakan daerah yang kaya potensi mulai dari sumberdaya alam, perkebunan, hingga pertambangan. Tapi karena tidak punya kewenangan, daerah tidak bisa berbuat banyak dengan kawasan perbatasan. Bila kondisi ini dibiarkan berlarut, bisa mengancam keutuhan Negara Kesatuan Republik Indonesia (NKRI). Hal tersebutlah yang melatari permintaan otonomi khusus untuk kawasan Kalimantan ini (http://tantocenter.blogspot.com/1 Juni 2008). 


\section{Proses Pengajuan Dan Aktor}

Komite Nasional Pemuda Indonesia (KNPI) Kaltim merupakan organisasi kepemudaan setempat yang termasuk paling lantang menyuarakan tuntuan otsus bagi Kaltim. Pada beberapa bulan terakhir tahun 2012, KNPI Kaltim gencar melancarkan aksinya dengan melakukan demo menuntut otonomi khusus (otsus) bagi Kalimantan Timur (Kaltim). KNPI Kaltim mengklaim bahwa mereka banyak mendapat dukungan dari luar Kaltim, bukan hanya dari masyarakat Kaltim. Mereka sempat mengancam akan melakukan demo di Istana Negara, Jakarta, dan bahkan akan memblokir Bandara Sepinggan, Balikpapan (http://www.kaltimpost.co.id, 23 Oktober 2012). Akan tetapi, sampai tulisan ini dibuat kedua rencana tersebut belum terealisasi.

Guna memantapkan aksinya, KNPI melakukan konsolidasi dengan beberapa organisasi kepemudaan yang hadir pada malam dialog rakyat "Judicial Review Ditolak, Otonomi Khusus Jawabannya” di salah satu kafe di Samarinda, tanggal 19 Oktober 2012. KNPI pada hari Sumpah Pemuda, 28 Oktober 2012 mengundang dialog mengundang semua unsur perwakilan masyarakat dan mahasiswa untuk ikut menindaklanjuti seruan "Otsus Kaltim atau Kaltim Merdeka". Dalam retorikanya KNPI melihat bahwa untuk memperjuangkan keadilan bagi Kaltim tidak cukup dengan jalur konstitusional, tapi Kaltim harus memiliki perjuangan yang lebih heroik. Perlu serangkaian demo-demo guna menyadarkan pemerintah pusat mengenai perlunya memberikan otsus kepada Kaltim. Tentu bermaksud hendak menambah tekanan kepada pemerintah pusat, KNPI Kaltim memperingatkan bahwa jika pemerintah pusat tidak mengabulkan tuntutan otsus Kaltim dan bila serangkaian aksi belum pula menyadarkan pemerintah, maka bukan tidak mungkin bila terjadi hal yang fatal seperti gerakan separatis yang ada di Aceh dan Papua. Ini karena baik Aceh maupun Papua mendapatkan otsus setelah melawan Jakarta (http://www. kaltimpost.co.id, 23 Oktober 2012).

Mungkin pihak KNPI Kaltim-lah yang pertama kali mencuatkan wacana 'Kaltim Merdeka' atau setidaknya menjadi Otsus, sebagaimana yang disampaikan oleh Ketua DPD KNPI Kaltim, Yunus Nusi. Akan tetapi KNPI sendiri sebenarnya tidak sepenuhnya bertekad memisahkan diri karena yang lebih dituntut ialah otsus Kaltim. KNPI lebih condong menawarkan adanya otonomi khusus (Otsus), seperti yang dinikmati Papua dan Nangroe Aceh Darussalam (NAD), sebagaimana terlihat dari ucapan Yunus (http://diskominfo. kaltimprov.go.id, 30 Oktober 2012):

"Kita masih merasakan ketimpangan pembangunan di berbagai bidang dengan pembangunan di Pulau Jawa. Jalanan misalnya masih berlubanglubang menganga di sana sini, padahal Kaltim memiliki sumberdaya alam (SDA) berlimpah. Sedang Aceh dan Papua yang sudah mendapat Otsus lebih baik. Kita tidak ingin keluar NKRI, tapi kita harus berjuang bersama untuk mendapatkan Otsus."

Sikap keras KNPI Kaltim muncul setelah kandasnya upaya judicial review (JR) atau uji materiil yang diajukan ke MK. Gagasan otonomi khusus hingga Kaltim merdeka lahir setelah tidak dikabulkannya gugatan judical review (uji materi) Provinsi Kaltim terhadap Pasal 14 huruf (e) dan (f) UU No 33 Tahun 2004 
tentang Pertimbangan Keuangan antara Pemerintah Pusat dan Pemerintah Daerah yang diprakarsai oleh kelompok yang menamakan diri Majelis Rakyat Kaltim Bersatu (MRKTB).

Majelis Rakyat Kaltim Bersatu (MRKTB), Abraham Ingan, sebagai pihak yang mengusung judicial review menyatakan kekecewaannya dengan penolakan MK. Namun bagi MRKTB langkah Kaltim masih terbuka untuk mendapatkan hak dana bagi hasil migas yang lebih baik. Jika MK sudah memutuskan menolak JR, maka perjuangan lain bisa dilakukan. Caranya, dengan menyerahkan sepenuhnya kepada masyarakat. Jadi, perlu dilakukan perjuangan melalui jalur lain, kendati MRKTB tetap menginginkan langkah yang juga konstitusional, seperti mendorong para wakil rakyat Kaltim di pusat lebih serius memperjuangkan keinginan masyarakat. MRKTB juga meminta DPRD Kaltim dan Gubernur Kaltim Awang Faroek Ishak agar lebih berani mendukung langkah perjuangan ini. Jangan sampai pemimpin dan rakyatnya tidak sehati. Usulan lain ialah dengan terlebih dahulu membuat Peraturan Daerah (Perda) tentang pengelolaan sumber keuangan daerah. Keberadaan perda tersebut berguna untuk menunjukkan kepada pemerintah pusat bahwa masyarakat Kaltim menderita dengan digagalkannya JR (http://www. samarindatepian.com, 21 October, 2012).

MRKTB sendiri bukanlah sebuah organisasi yang solid, karena terdapat friksi internal yang cukup kuat di dalamnya. Friksi terkait masalah penggunaan keuangan yang tidak transparan dan terdapatnya egosentrisme sebagian kalangan etnik Dayak, khususnya setelah organisasi tersebut dipimpin oleh Abraham. Ada dugaan bahwa sebagian pengurus MRKTB justru mencari "makan" dari organisasi tersebut. Hal ini cukup beralasan mengingat di balik kerasnya dengung perjuangan keadilan bagi Kaltim, banyak dana yang mengalir ke dalam organisasi tersebut, di mana terdapat indikasi penggunaan dana yang tidak pada tempatnya atau tidak bisa dipertanggungjawabkan. Dana yang mengalir ke MRKTB tidaklah kecil dan berasal dari sumbangan pelbagai pihak, baik pihak pemerintah daerah setempat maupun dari kalangan perusahaan (wawancara dengan Asisten Bidang Pembangunan Kaltim, Ali Fathur Rahman, 13 Mei 2013, di Samarinda). Kalangan perusahaan-perusahaan yang ada di Kaltim mungkin demi pertimbangan keamanan merasa terpaksa memberi dukungan terhadap tuntutan JR, karena sebetulnya sebuah dukungan resmi bisa jadi akan memberatkan dalam negosiasi bisnis mereka di kemudian hari dengan pemerintah pusat (wawancara dengan Pemred Kaltim Post, Rizal Juraid, 13 Mei 2013, di Samarinda).

MRKTB terdiri dari berbagai unsur etnik yang ada di Kaltim, baik itu Melayu, Banjar, Bugis, Jawa, maupun Dayak sendiri. Akan tetapi, sebagian unsur di luar Dayak melihat bahwa eksponen Dayak di dalam MRKTB selalu merasa bahwa mereka adalah pemilik MRKTB, sebagaimana cerminan bahwa mereka menganggap sebagai pemilik Kalimantan (wawancara dengan Ketua KNPI Kaltim, Yunus Nusi, 15 Mei 2013, di Samarinda). MRKTB tidak bisa diklaim merepresentasikan etnik Dayak saja karena di dalamnya terdiri dari pelbagai unsur etnik, kendati di dalamnya terlihat Dayak lebih dominan (wawancara dengan Pemred Kaltim Post, Rizal Juraid, 13 Mei 2013, di Samarinda). Keberadaan eksponen Dayak di dalam MRKTB merupakan representasi dari sebagian kalangan yang telah berpendidikan dan tinggal di perkotaan. Di pihak lain, cukup wajar bila 
dari kalangan etnik Dayak yang paling gencar menyuarakan keadilan pembangunan, karena sebagai penduduk lokal kondisi kehidupan mereka relatif masih tertinggal. Komunitas Dayak yang banyak tinggal di wilayah pedalaman adalah yang paling merasakan bagaimana Indonesia gagal membangun kawasan pedalaman, khususnya di Kaltim, sementara di lain pihak sumber daya alam Kaltim yang disedot oleh pemerintah pusat terletak di pedalaman (wawancara dengan Asisten bidang Pembangunan Pemprov Kaltim, Ali Fathur Rahman, 13 Mei 2013, di Samarinda).

Perlu diketahui bahwa hubungan antaretnik di Kaltim sendiri dalam beberapa tahun belakangan terlihat mulai menunjukkan kerawanan karena terlihat kurang harmonis dan toleransi antaretnik sudah mulai merenggang. Hal ini sebagian disebabkan oleh kenyataan bahwa penduduk lokal tidak memiliki posisi dominan dari sisi populasi, sementara secara ekonomi pendatang lebih menguasai perekonomian. Beruntung kalangan pendatang terlihat masih dalam posisi menahan diri dan lebih bersabar (wawancara dengan Pemred Kaltim Post, Rizal Juraid, 13 Mei 2013, di Samarinda) sehingga tatkala terjadi gesekan etnik seperti di Kabupaten Kutai Barat maka situasinya relatif masih dapat dikendalikan http://www.merdeka.com, 26 november 2012.

Sementara para pihak menilai wajar jika rakyat Kaltim menggugat, namun tidak sedikit pesimis jika gerakan ini bisa menggugah nurani pemerintah pusat. Boleh jadi pula gerakan ini hanya dilakukan oleh segelintir orang, dan belum merupakan aksi seluruh elemen masyarakat (http://www.kaltimpost.co.id, 23 Oktober 2012). Terlepas dari itu, yang jelas KNPI Kaltim tengah berupaya membakar semangat heroisme masyarakat Kaltim untuk menuntut keadilan. KNPI Kaltim sebagai penggagas Otsus menyatakan ide Otsus dan Kaltim merdeka merupakan langkah terakhir setelah menempuh jalur prosedural yang berakhir kalah. KNPI beralasan bahwa aspirasi rakyat di bawah tidak bisa dilakukan hanya dengan teoritis dan dialog saja, tapi harus dengan tindakan heroik agar lahir gejolak sehingga pemerintah pusat akan bergeming (http:// hizbut-tahrir.or.id/12 Desember 2012). Niscaya dalam fikiran mereka ialah perlunya ada semacam gerakan dan perlawanan guna menaikkan posisi tawar Kaltim, sebagai daerah vital yang punya kelebihan dari segi kekayaan alam, dibanding daerah lain.

Sikap keras KNPI setidaknya mewakili suara dari sebagian kalangan muda di Kaltim, khususnya dari unsur mahasiswa. Mereka merasa kekecewaan yang cukup mendalam terhadap penolakan Mahkamah Konstitusi (MK) atas judicial review (JR) atau uji materiil Pasal 14 huruf e dan f Undang-Undang No 33 Tahun 2004. Tak lama setelah penolakan MK tersebut digelar sejumlah dialog di Kaltim membahas perihal ini, dan tidak ketinggalan ada yang disiarkan melalui televisi setempat. Boleh jadi memang ada sebagian warga atau pemuda Kaltim yang sempat terinspirasi oleh wacana yang diangkat oleh KNPI dan mendukungnya, dengan menyatakan bahwa pemuda Kaltim harus memiliki semangat keberanian untuk bangkit dan berjuang membangun bangsa dan negara, terutama membangun Kaltim jadi lebih baik, yakni melalui tuntutan otsus Kaltim atau Kaltim merdeka. Itu mencuat tentu sebagai wujud kemarahan dan kekecewaan masyarakat yang selama ini terpendam. Masyarakat Kaltim sadar bahwa selama ini pemerintah pusat tidak bersungguh-sungguh dalam membangun Kaltim. 
Salah satunya dalam dialog rakyat bertajuk "Judicial Review Ditolak, Otonomi Khusus Jawabannya" digelar oleh Komite Nasional Pemuda Indonesia (KNPI) Kaltim, di kafe Djoeragan Kopi, Jalan Juanda, Samarinda, pada 20 Desember 2012. Dalam dialog yang berakhir hingga dini hari tersebut sempat tercetus seruan "Kaltim merdeka" dari peserta dialog. Ide radikal ini terutama gencar bergaung dari unsur pemuda dan mahasiswa, seperti Himpunan Mahasiswa Islam (HMI) Samarinda, Badan Eksekutif Mahasiswa (BEM) Universitas 17 Agustus, dan Pemuda Pancasila. Suara keras ini muncul sebagai wujud kekecewaan terhadap pemerintah pusat, sebagian lain juga karena kalangan mahasiswa merasa tidak pernah dilibatkan dalam proses pengajuan uji materiil UU No.33/2004 yang dimotori oleh MRKTB (http://www.samarindatepian. com, 21 October 2012).

Tuntutan otsus Kaltim atau "Kaltim Merdeka" mungkin baru sebatas retorika. Sebagian pihak berpendapat, boleh saja menggugat pemerintah pusat asalkan memiliki dasar yang kuat. Kendati melihat pula ketidakadilan pusat terhadap Kaltim, sebagian besar kalangan di Kaltim menilai tuntutan otsus Kaltim atau bahkan Kaltim merdeka bukanlah solusi, sebab masalah utamanya adalah sesungguhnya Indonesia belum merdeka, karena secara realita SDA Indonesia masih dijajah oleh asing (http://hizbut-tahrir.or.id/12 Desember 2012). Ketimbang mengajukan aksi radikal seperti menuntut merdeka, sebagian besar kalangan di Kaltim lebih cenderung untuk melakukan perjuangan melalui jalur yang lebih demokratis. Alasannya ialah karena Kaltim berbeda dengan Aceh dan Papua yang masyarakatnya bersifat homogen, sementara Kaltim lebih heterogen sehingga pengerahan massa akan sulit dilakukan. Di antara perjuangan yang dapat dilakukan ialah dengan mendorong agar salah satu tokoh Kaltim bisa menjadi menteri di kabinet agar kebijakan menteri tersebut bisa pro kepada Kaltim daripada menuntut Kaltim merdeka. Mereka merujuk pada keberhasilan Kalimantan Selatan yang punya Menteri Riset dan Teknologi, Gusti Muhammad Hatta (http://www.kaltimpost.co.id, 23 Oktober 2012).

Sesungguhnya memang belum semua pihak sepakat dengan tuntutan otsus Kaltim ini, apalagi sampai pada ancaman merdeka. Agaknya benar bahwa ini baru merupakan keinginan segelintir orang. Belakangan juga terbukti bahwa tuntutan tersebut hanya sebatas sikap reaktif atas ditolaknya JR oleh MK, waktu berlalu isu otsus Kaltim dengan cepat surut dan semakin kehilangan gaungnya. Kalaupun ada yang masih membicarakannya hanya orang-orang tertentu satu-dua orang tokoh pemuda maupun sedikit kalangan akademisi dan di birokrasi. Bagi yang masih membicarakan tuntutan otsus, tidak jarang mereka belum memiliki format otsus seperti apa yang mereka inginkan, termasuk KNPI sendiri belum memiliki format dimaksud kecuali sebatas pemahaman bahwa bila otsus diberikan maka Kaltim akan menikmati bagi hasil yang setara dengan yang diterima oleh Aceh dan Papua kini. Memang ada kalangan di birokrasi atau akademisi yang telah mampu menjelaskan format otsus yang diinginkan, akan tetapi di antara mereka sendiri belum pernah saling bertemu untuk berdiskusi guna merumuskan format otsus semacam apa yang diinginkan oleh Kaltim.

Kalangan birokrasi di pemerintahan provinsi Kaltim jelas terlihat enggan mewacanakan tuntutan otsus Kaltim. Sekretaris Daerah Provinsi Kaltim, H Irianto Lambrie, menyatakan tidak sependapat dengan aspirasi para pemuda Kaltim yang 
mewacanakan Kaltim harus menjadi daerah Otonomi Khusus (Otsus) seperti Aceh dan Papua. Terlebih kalau Kaltim disebut harus 'Merdeka' atau memisahkan dari NKRI (Negara Kesatuan Republik Indonesia). Wacana 'Kaltim Merdeka' atau menjadi daerah Otsus dianggap terlalu berlebihan (http://diskominfo.kaltimprov.go.id, 30 Oktober 2012).

Pihak Sekda Provinsi Kaltim membandingkan bahwa PAD (pendapatan asli daaerah) Papua dan Aceh yang tidak lebih baik dari Kaltim yang PAD-nya 40-50 persen bersumber dari APBD. Ia berpendapat, sebenarnya Kaltim sudah bisa dikatakan otonom, mengingat APBD Kaltim dewasa ini telah jauh lebih besar ketimbang Aceh. APBD Aceh, misalnya, hanya sekitar Rp 6 triliun, sedang Kaltim sudah mencapai Rp 13 triliun yang 40-50 persennya didapat dari PAD.

Pemda Provinsi Kaltim meminta semua pihak, terutama pemuda Kaltim, untuk memahami betul makna otonomi sebenarnya dan melihat permasalahan secara lebih komprehensif. Pihak Pemda mengaku amat gusar dengan wacana otsus Kaltim, yang belakangan ditarik menjadi tuntutan merdeka, seraya menilai wacana seperti itu sangat berbahaya jika tidak dipahami dengan baik dan benar. Pihak Pemda Provinsi Kaltim lebih mengajak semua pihak di Kaltim untuk bangkit berjuang mendukung revisi undang-undang agar Kaltim sebagai salah satu daerah penghasil minyak dan gas bumi mendapat dana perimbangan keuangan yang lebih besar.

Gubernur Kaltim, Awang Faroek Ishak, juga menilai bahwa apa yang dilakukan KNPI dan sejumlah elemen kepemudaan tersebut sebatas wacana, dan sebaiknya diadakan diskusi untuk membahas apa yang sedang diperjuangkan KNPI. Awang Faroek sempat meminta kepada KNPI Kaltim yang mewacanakan menuntut otonomi khusus (otsus) dan Kaltim merdeka agar tidak terburu-buru melakukannya karena pemerintah provinsi masih berjuang di jalur konstitusional. (http://www.kaltimpost.co.id, 23 Oktober 2012).

Kendati judicial review telah gagal di MK, Pemerintah Provinsi Kaltim tetap yakin bahwa cara terbaik yang dapat ditempuh agar Kaltim mendapat keadilan pembagian hasil, adalah dengan menuntut revisi UU Nomor 33 tahun 2004, yakni tentang pembagian keuangan pemerintah pusat dan pemerintah daerah. Terkait dengan itu, maka Gubernur Kaltim meminta agar semua anggota Dewan Perwakilan Daerah (DPD) RI dan Dewan Perwakilan Rakyat (DPR) RI asal Kaltim, agar memiliki tanggung jawab dan merasa wajib memperjuangkan, yakni agar pembagian dana perimbangan keuangan bisa adil bagi Kaltim. Sementara gubernur yang merupakan wakil pemerintah pusat di daerah, selalu siap memimpin semua bupati dan wali kota, termasuk DPRD se-Kaltim untuk melakukan rapat dengar pendapat dengan Pansus Pembahasan Revisi UU No.33/2004 di DPR RI. Bahwa kegagalan Kaltim melakukan JR tentang pasal 14 huruf e dan huruf f pada UU Nomor 33/2004, harus tetap disikapi secara bijaksana. Sedangkan upaya mendukung revisi UU 33/2004 yang siap dilakukan, merupakan salah satu alternatif perjuangan demi menuntut keadilan dalam pembagian dana perimbangan (http://www. antarakaltim.com, 29 Oktober 2012). 
Kalau dilihat dari realisasi lifting minyak bumi saja, Provinsi Kaltim mencapai 17,377 juta barel per tahun, sedangkan Kabupaten Kukar bahkan realisasi liftingnya mencapai 22,158 juta barel. Digabung dengan realisasi lifting beberapa kabupaten lain di sana, maka untuk seluruh wilayah Kaltim, total lifting dari minyak bumi mencapai 47,436 juta barel, berarti Kaltim menyumbang 19,35 persen dari realisasi produksi minyak bumi nasional yang mencapai 245,129 juta barel untuk tahun 2012. Sementara realisasi lifting gas alam Provinsi Kaltim mencapai 369,634 mmbtu, Kabupaten Kukar 430,987 juta mmbtu, ditambah realisasi dari beberapa kabupaten lain di wilayah tersebut maka total realisasi gas alam untuk seluruh Provinsi Kaltim mencapai 822,229 juta mmbtu. Jumlah tersebut memberi kontribusi 40,69 persen dari total realisasi gas nasional yang tercatat 2,021 juta mmbtu pada tahun 2012 (data dari Dinas Pertambangan Kaltim, 2013).

Di bidang kehutanan tidak ada satu batang kayupun yang tidak diatur oleh pemerintah pusat, dalam hal ini Kementerian Kehutanan, termasuk bidang perencanaan dan pemberian izin investasi semua ditangani oleh Pusat, sementara Dinas Kehutanan Kaltim hanya semacam pelaksana kegiatan. Hasil komoditas kayu Kaltim semua disetorkan ke pemerintah pusat, secara berkala Jakarta mengeluarkan rekon memperlihatkan berapa yang masuk dan menjadi bagian Kaltim, tentu saja dalam hal ini pihak daerah hanya bisa menerima begitu saja pembagian yang telah ditetapkan oleh Pusat, dan mungkin sedikit-sedikit protes kalau tidak sesuai karena Pemprov juga memiliki data yang dikumpulkan dari kabupaten-kabupaten. Pihak Kehutanan Provinsi Kaltim agak beruntung karena pihak kabupaten dapat mengumpulkan data-data dari perusahaan-perusahaan mengenai berapa besarnya produksi dan yang disetorkan ke Jakarta (wawancara denga Kepala Dinas Kehutanan Kaltim, Khairil Anwar, 17 Mei 2013, di Samarinda).

Agak berbeda ialah yang terjadi pada bidang pertambangan baik komoditas migas maupun tambang di mana pihak Pemprov maupun Pemkab tidak bisa mengakses informasi ke perusahaan-perusahaan, sehingga hanya Pusat yang memiliki datanya sementara pihak daerah sama-sekali tidak tahu-menahu. Pihak Dinas Pertambangan Kaltim mengibaratkan bahwa dalam masalah rekon pertambangan, seluruh daerah di Indonesia bagaikan "kambing congek", di mana Pusat mengajukan data, sementara daerah-daaerah hanya tinggal mengamini saja. Sering terjadi lantaran pihak perusahaan langsung menyetor ke Pusat maka tidak terdapat data yang lengkap dari daerah mana perusahaan penyetor tadi. Hal ini membuat banyak dana bagi hasil tidak dapat diserahkan ke daerah yang berhak, karena tidak ketahuan daerah mana pemiliknya, dimana setiap tahunnya uang mengendap tersebut di kas negara bisa mencapai Rp 1 triliun. Bertahun-tahun sistem semacam ini diberlakukan dan uang mengendap semakin menggelembung, sementara pemerintah pusat tidak mampu mengatasi permasalahan ini lantaran pemerintah pusat terlalu banyak pekerjaan juga (wawancara dengan Kabid Pertambangan Umum Dinas Pertambangan Kaltim, Freddy, 14 Mei 2013, di Samarinda).

Bukan hanya pihak provinsi, pihak kabupaten juga tidak pernah tahu berapa produksi dari daerah. Daerah tidak pernah mendapat tembusan dari Kementerian ESDM, sehingga daerah tidak bisa melakukan cross check. Ini pada akhirnya membuat daerah sungguh tidak tahu apakah daerah betul-betul memperoleh 15 
persen bagi hasil. Sementara di pihak lain, perusahaan-perusahaan yang ada di daerah semua bersikap tertutup, dan menolak untuk mengungkapkan data produksi mereka (wawancara dengan Wakil Bupati Kukar, Ghufron Yusuf, 16 Mei 2013, di Tenggarong).

Padahal di pihak lain pada bidang pertambangan batubara misalnya daerah Kaltim menghadapi permasalahan besar akibat eksploitasi yang tidak terkendali dan berpotensi menimbulkan kerusakan lingkungan yang luar biasa. Kaltim merasa bahwa terlalu besar yang disumbangkan kepada Negara, sementara daerah Kaltim akan menghadapi masalah besar di masa mendatang. Jangan sampai Kaltim menyumbang terus, tapi Kaltim sendiri lalu menjadi sakit. Terlebih ketika suatu saat nanti SDA Kaltim bakal habis, mengingat beberapa jenis tambang seperti batu baru bersifat tidak terbarukan (non renewable). Selama ini pemerintah pusat dinilai tidak memiliki kebijakan untuk membatasi kuota produksi, yang dipikirkan oleh Jakarta ialah hanya bagaimana produksi batubara Kaltim digenjot dan dikuras terus, tanpa sedikitpun memikirkan bagaimana dampak terhadap rusaknya daya dukung lingkungan. Apabila untuk mendapatkan 1 ton batubara harus mengupas tidak kurang dari 10 ton tanah, sementara bila produksi batubara Kaltim per tahunnya bisa berkisar 220 juta ton maka tanah yang harus dikeruk setiap tahunnya mencapai tiga miliar kubik tanah (wawancara dengan Kabid Pertambangan Umum Dinas Pertambangan Kaltim, Freddy, 14 Mei 2013, di Samarinda). Katakanlah diasumsikan produksi konstan, maka dengan mudah dapat dihitung bahwa dalam tempo 10 tahun terdapat 10 miliar kubik tanah yang harus dikeruk. Betapa kenyataan ini amat luar biasa besar dalam potensi merusak lingkungan. Tidak mengherankan bila akibatnya sudah mulai dirasakan oleh daerah Kaltim dewasa ini dimana membuat sungaisungai menjadi dangkal dan air meluber yang pada akhirnya menimbulkan bencana banjir. Akibat ekploitasi sumber daya alam yang tidak terkendali selama ini telah membuat bumi Kaltim telah menjadi luka, dan mungkin sudah terserang tetanus, lantaran alamnya sudah tidak seimbang Dari sisi inilah argumentasi mengenai pentingnya pemberian otsus kepada Kaltim, yakni adanya kekhususan untuk dapat mengelola sumber daya alamnya sendiri secara mandiri dan rasional. Dengan adanya kekhususan tersebut maka Kaltim akan bisa mengelola sendiri berapa besar produksi tiap tahunnya agar terkontrol dan tidak menimbulkan dampak buruk bagi lingkungan. Ini pada gilirannya akan menjamin kelangsungan hidup masyarakat Kaltim dan kelestarian lingkungan. Jadi, tambangnya boleh diambil tapi alam sekitar harus tetap aman dan tetap hijau (wawancara dengan Kabid Pertambangan Umum Dinas Pertambangan Kaltim, Freddy, 14 Mei 2013, di Samarinda).

Kaltim praktis mengalami ketertinggalan di bidang infrastruktur, khususnya jalan. Ketertinggalan infrastuktur telah membuat sejumlah wilayah kecamatan nyaris terisolasi karena tidak dapat terhubung dengan ibukota kabupaten. Kondisi mana telah membuat menderita penduduk setempat, akibat mahalnya harga barangbarang, dan termasuk mahalnya harga material untuk melaksanakan pembangunan. Di sejumlah tempat di Kabupaten Malinau, seperti Desa Long Nawang (Kec. Kayan Hulu) dan Desa Long Apung (Kec. Kayan Selatan), belum dapat terhubung dengan Malinau sebagai ibukota kabupaten. Akibatnya ketika hendak membangun jembatan di sana, maka materialnya harus dibeli dari perbatasan Negara bagian 
Serawak, Malaysia (wawancara dengan Joko, Dinas PU Kaltim, 15 Mei 2013, di Samarinda).

Kecuali amat tertinggalnya infrastruktur, kondisi jalan-jalan di Kaltim juga telah mengalami kerusakan di sana-sini. Buruknya kondisi jalan di Kaltim merupakan salah satu hal yang paling banyak dikeluhkan oleh orang di sana. Baik kalangan pejabat di Kaltim maupun masyarakat umum biasanya suka membandingkan kondisi jalan di Kaltim dengan di Kalsel, melewati jalan-jalan di Kalsel kita akan bisa tertidur pulas menggambarkan mulusnya jalan di provinsi sebelah, sementara kita akan terbangun dari tidur begitu memasuki wilayah Kaltim lantaran banyak jalan yang rusak dan berlubang-lubang. Bagi masyarakat Kaltim kondisi ini tentu saja mengherankan, bagaimana mungkin Kaltim yang kontribusinya bagi perekonomian nasional begitu besar berkat kekayaan SDA nya memiliki kondisi infrastruktur jalan yang lebih buruk dari Kalsel yang tidak begitu kaya SDA. Banyak kalangan di Kaltim juga menyatakan bahwa Kaltim memiliki wilayah yang begitu luas, dengan demikian jalan yang harus ditangani juga panjang yakni bisa mencapai $2100 \mathrm{KM}$ untuk kategori jalan nasional, kondisi mana tentu tidak boleh disamakan anggarannya dengan Kalsel.

Kerusakan jalan-jalan di wilayah Kaltim khususnya terjadi semenjak tahun 2009 tatkala eksploitasi besar-besaran batubara mulai berlangsung. Akibat tidak adanya pembatasan di mana kendaraan-kendaraan milik perusahaan batu bara yang bermuatan berat masih dapat hilir mudik di jalanan umum, pada saat petugas lengah, di mana pemerintah setempat sendiri tidak dapat mengawasi selama 24 jam penuh (wawancara dengan Joko, Dinas PU Kaltim, 15 Mei 2013, di Samarinda). Banyak dari jalan-jalan yang rusak berstatus jalan nasional, di mana mestinya untuk perbaikan merupakan tanggung jawab pemerintah pusat. Akan tetapi pemerintah pusat sering kali menutup mata atas kondisi kerusakan jalan di Kaltim, akibatnya membuat pemerintah daerah setempat terpaksa menangani pekerjaan-pekerjaan perbaikan yang mestinya merupakan tanggung jawab pemerintah pusat, yakni memperbaiki jalan yang berstatus jalan nasional. Ini dari segi administratif bisa dianggap melanggar oleh BPK, namun kalau tidak diperbaiki maka kerusakan jalan-jalan akan semakin parah (wawancara dengan Joko, Dinas PU Kaltim, 15 Mei 2013, di Samarinda).

Di balik upaya untuk meminta bagi hasil yang lebih adil, entah itu melalui JR, melalui lobby di DPR, atau mewacanakan tuntutan otsus, yang menjadi pertanyaan ialah bagaimana kemampuan pihak pemda di Kaltim maupun pemdapemda kabupaten di sana terhadap pengelolaan dana yang relatif besar. Dua kenyataan yang selama ini menjadi keraguan banyak pihak ialah menyangkut relatif besarnya dana yang tidak dapat digunakan dalam bentuk Silpa maupun belum efektifnya penggunaan dana terkait maraknya kasus korupsi di sana. Dalam hal terakhir, orang biasanya akan merujuk pada kasus Kaltim maupun Kabupaten Kukar di mana uang yang melimpah tidak sertamerta membuat rakyatnya sejahtera, justru merebaknya kasus-kasus dugaan korupsi di sana (http://news.detik.com, 19 Agustus 2010). Sementara itu menyangkut Silpa, penyerapan anggaran Provinsi Kaltim hanya 86 persen, itu artinya Pemprov Kaltim belum maksimal dalam memaksimalkan anggaran (wawancara dengan Wakil Ketua DPRD Kaltim, Sofyan Alex, 14 Mei 2013, di Samarinda). Demikian pula dengan Kabupaten Kukar dengan 
APBD Rp 6 triliun telah terjadi Silpa hingga 2 triliun (wawancara dengan Wakil Bupati Kukar, Ghufron Yusuf, 16 Mei 2013, di Tenggarong), berarti anggaran yang tidak bisa digunakan mencapai sekitar 30 persen lebih. Kondisi yang sama kita saksikan di tingkat provinsi dimana terdapat kasus silpa yang relatif besar. Kenyataan demikian lantas membuat orang meragukan kesiapan pemerintah daerah setempat apabila kelak tuntutan dana perimbangan Kaltim dipenuhi atau otsus diberikan.

Terkait begitu besarnya silpa di Kaltim antara lain karena keterlambatan penerimaan anggaran, di samping dewasa ini orang banyak yang takut dan hati-hati dalam mengelola anggaran. Bila terjadi kesalahan prosedur dalam pengelolaan anggaran, maka akan dapat masuk penjara (wawancara dengan Ketua Pusat Perencanaan Pembangunan dan Keuangan Daerah Universitas Mulawarman, 15 Mei 2013, di Samarinda). Akan tetapi, bila mau jujur harus diakui, setelah Kaltim memiliki banyak uang justru tidak bisa berbuat apa-apa, banyak SKPD yang kelihatan kurang dinamis dan mungkin dapat disebut "ogah-ogahan" (wawancara dengan Wakil Ketua DPRD Kaltim, Sofyan Alex, 14 Mei 2013, di Samarinda). Sebagaimana terjadi di Kabupaten Kukar, pihak Pemkab Kukar beralasan bahwa itu terkait penerimaan setiap tahunnya diperoleh pada akhir masa anggaran yang nilainya mencapai Rp 1 triliun lebih. Tentu saja tidak mungkin menghabiskan yang sebesar itu dalam tempo tiga bulan. Namun, di luar masalah tersebut, mereka mengakui bahwa lemahnya penyerapan anggaran juga terkait erat dengan masalah kapasitas SDM yang belum mampu mengelola dana besar, khususnya pada SKPD yang mengelola dana besar seperti Dinas PU dan Dinas Pendidikan. Yang paling bermasalah ialah pada Dinas PU. Sebagai gambaran pembangunan infrastruktur diprioritaskan untuk menghilangkan keterisolasian daerah, antarwilayah kecamatan juga antara kecamatan dengan ibukota kabupaten. Untuk tahun 2013 saja, alokasi untuk pembangunan jalan dan jembatan mencapai dua triliun rupiah, yang terdiri atas ratusan item pekerjaan. Pihak Dinas PU Kab. Kukar mengalami kesulitan luar biasa dalam proses pelelangan lantaran setiap satu panitia lelang harus menyelesaikan 40 unit lelang dalam satu tahun. Sesungguhnya itu merupakan tugas yang hampir tidak masuk akal. Ini terjadi karena pegawai di lingkungan Dinas PU yang mampu menjadi panitia lelang hanya beberapa orang saja, padahal yang harus dilelang mencapai ratusan item pekerjaan. Lemahnya SDM di Dinas PU diakui karena pada proses rekruitmen memang tidak bagus. Jumlah pegawai Dinas PU memang berlebihan, tapi dari segi kualitas masih kurang khususnya dalam kemampuan bidang teknologi informasi (wawancara dengan Sekretaris Bappeda Kab. Kukar, Wiyono, 16 Mei 2013, di Tenggarong.)

Dengan menengok pada masih begitu rendahnya penyerapan anggaran dan lemahnya kualitas SDM pada SKPD-SKPD di Kaltim maka tuntutan otsus secara obyektif menjadi tidak rasional, karena secara logika dengan adanya tambahan dana bagi hasil yang jauh lebih besar maka besaran silpa bakal jauh lebih menggelembung lagi.

\section{Kesimpulan}

Otsus Kaltim merupakan tuntutan yang boleh dibilang prematur dan setengah hati dilihat dari beberapa alasan: 
1. Munculnya tuntutan tersebut di Kaltim praktis tidak terdesain dengan baik, karena terkesan merupakan usulan yang sifatnya reaktif menyusul ditolaknya tuntutan judicial review (JR) atau uji materi atas UU No.33/2004 tentang Perimbangan Keuangan Pusat dan Daerah yang pembagiannya dinilai tidak adil bagi Kaltim. Tuntutan otsus Kaltim sifatnya hanya kemarahan sesaat pada saat ditolaknya JR oleh MK, bahkan kala itu ada pula muncul gagasan yang lebih ekstrim yakni Kaltim merdeka apabila tuntutan otsus Kaltim ditolak Belakangan waktu berlalu, gaung tuntutan otsus juga dengan cepat surut dan kurang terdengar lagi di masyarakat. Penilaian prematur dan setengah hati juga dapat dibuktikan dengan belum adanya dokumen tertulis maupun desain yang jelas mengenai format tuntutan otsus semacam apa yang hendak diperjuangkan oleh Kaltim. Yang ada barulah sebatas serpihan-serpihan gagasan yang saling lepas yang dilontarkan oleh sebagian kalangan akademisi atau sebagian kalangan di birokrasi, gagasan mana belum diformulasikan secara utuh sebagai suatu konsep.

2. Tuntutan otsus Kaltim sendiri memiliki sejumlah kelemahan:

a. Usulan tersebut hanya merupakan keinginan dari sebagian kecil masyarakat di Kaltim, dalam hal ini kalangan pemuda khususnya yang dimotori oleh KNPI di Kaltim maupun dari sebagian kecil kalangan akademisi di sana.

b. Pelbagai eksponen masyarakat yang ada di Kaltim cenderung belum memiliki sikap yang cukup solid untuk mendesakkan tuntutan otsus Kaltim, mengingat Kaltim merupakan daerah yang heterogen dan multietnik.

c. Ada sementara yang mencurigai bahwa tuntutan otsus hanyalah merupakan "dagangan politik" semata dari kalangan tertentu. Kecurigaan ini cukup beralasan bila menyimak sepak terjang organisasi sebelumnya yang memperjuangkan JR yakni MRKTB juga diterpa banyak isu yang kurang sedap, menyangkut dominasi etnik tertentu di dalam organisasi tersebut dan adanya kepentingan material serta penggunaan dana-dana yang tidak dapat dipertanggungjawabkan.

d. Adanya ancaman tindakan radikal dari sekelompok tertentu untuk melakukan sejumlah aksi terkait tuntutan otsus seperti hendak menutup bandara Sepinggan dan menduduki istana Negara di Jakarta hingga saat ini belum satupun yang terbukti, sehingga hanya dianggap sebagai "gertak sambal". Taktik mana bukan tidak mungkin telah terbaca oleh pemerintah pusat, sehingga kecil kemungkinan pemerintah pusat merespon tuntutan otsus Kaltim. 
e. Sementara tuntutan yang lebih radikal semacam Kaltim merdeka secara obyektif tidak memiliki pendukung yang patut diperhitungkan, karena suara yang radikal tersebut sementara baru terdengar dari KNPI setempat. Dan, pemikiran radikal semacam ini banyak ditentang di sebagian besar kalangan di Kaltim.

f. Pihak Pemprov Kaltim maupun kalangan Pemkab di sana yang hampir secara tegas memperlihatkan dukungan terhadap tuntutan JR, memiliki sikap yang berbeda terhadap tuntutan otsus Kaltim. Dalam hal tuntutan otsus, pihak Pemda setempat terkesan enggan memberi dukungan karena merasa "sungkan" terhadap pemerintah pusat. Kendati mungkin akan senang dan diuntungkan bila tuntutan otsus dipenuhi oleh pemerintah pusat, namun pihak Pemda setempat lebih memilih jalur yang lebih lunak menyusul ditolaknya JT, yakni dengan jalur perjuangan melalui DPR. Kendati bila dikaji lagi maka relatif kecil peluang bagi Kaltim untuk dapat melakukan revisi UU 33/2004 melalui jalur DPR, mengingat kecilnya kekuatan politik wakil-wakil Kaltim di DPR.

g. Dari sisi rasionalitas tuntutan otsus Kaltim belum pula memiliki argumentasi yang kuat mengingat adanya kenyataan yang masih saling bertolak belakang:

a) Dari satu sisi mungkin kita dapat memahami bagaimana tuntutan otsus muncul karena sebagai daerah yang memiliki kekayaan SDA maka Kaltim bersama daerah serupa lain seperti Sumsel, Riau, Aceh, dan Papua layak mendapatkan otsus dari sisi ekonomi. Apabila Aceh dan Papua telah menikmatinya lantaran latar belakang konflik di kedua wilayah tersebut, maka sudah sepatutnya Kaltim, Riau, dan Sumsel juga mendapatkannya. Bagaimana mungkin "anak yang patuh" justru dipandang sebelah mata, sementara "anak nakal" seperti Aceh dan Papua justru memperoleh otsus. Tuntutan otsus Kaltim relatif rasional dilihat dari sisi ekonomi karena tingkat kesejahteraan yang diukur dari sejumlah indikator terlihat amat rendah, dan jauh berada jauh di belakang daerah-daerah yang tidak kaya SDA. Hal ini karena kekayaan Kaltim lebih banyak tersedot dan dinikmati oleh orang luar Kaltim dibandingkan yang dinikmati oleh masyarakat Kaltim sendiri. Hal ini tercermin pula dari amat kecilnya bagi hasil yang diperoleh Kaltim dibandingkan dengan begitu besarnya kontribusi kekayaan alam kepada NKRI.

b) Dilihat dari sisi lingkungan Kaltim merasa bahwa terlalu besar yang disumbangkan kepada Negara, sementara daerah Kaltim akan menghadapi masalah besar di masa mendatang. Terlebih ketika 
suatu saat nanti SDA Kaltim bakal habis, mengingat beberapa jenis tambang seperti batu baru bersifat tidak terbarukan (non renewable). Bidang pertambangan batubara misalnya daerah Kaltim menghadapi permasalahan besar akibat eksploitasi yang tidak terkendali dan berpotensi menimbulkan kerusakan lingkungan yang luar biasa. Selama ini pemerintah pusat dinilai tidak memiliki kebijakan untuk membatasi kuota produksi, yang dipikirkan oleh Jakarta ialah hanya bagaimana produksi batubara Kaltim digenjot dan dikuras terus, tanpa sedikitpun memikirkan bagaimana dampak terhadap rusaknya daya dukung lingkungan. Akibat ekploitasi sumber daya alam yang tidak terkendali selama ini telah membuat bumi Kaltim telah menjadi luka. Dari sisi inilah penulis melihat relatif kuatnya argumentasi mengenai pentingnya pemberian otsus kepada Kaltim, yakni adanya kekhususan untuk dapat mengelola sumber daya alamnya sendiri secara mandiri dan rasional. Dengan adanya kekhususan tersebut maka Kaltim akan bisa mengelola sendiri berapa besar produksi tiap tahunnya agar terkontrol dan tidak menimbulkan dampak buruk bagi lingkungan. Ini pada gilirannya akan menjamin kelangsungan hidup masyarakat Kaltim dan kelestarian lingkungan.

c) Akan tetapi di pihak lain tuntutan otsus Kaltim mengandung kelemahan yang cukup nyata bila kita menengok pada sisi good governance dan kesiapan SDM setempat. Dua kenyataan yang selama ini menjadi keraguan banyak pihak ialah menyangkut relatif besarnya dana yang tidak dapat digunakan dalam bentuk Silpa maupun belum efektifnya penggunaan dana terkait maraknya kasus korupsi di sana.

d) Menyangkut Silpa, penyerapan anggaran Provinsi Kaltim hanya mencapai 86 persen, demikian pula dengan kabupaten dengan dana besar seperti Kukar memiliki silpa hingga dua triliun per tahunnya atau sekitar 30 persen lebih. Terkait begitu besarnya silpa ini, di samping masalah anggaran yang terlambat turut maupun sikap yang amat hati-hati dalam pengelolaan anggaran, itu dapat diartikan pula sebagai kekurangmampuan Kaltim untuk berbuat "banyak" dengan anggaran yang besar. Bagaimana pula jadinya bila anggaran akan meningkat lagi tatkala tuntutan otsus dipenuhi oleh pemerintah pusat. Peneliti juga menemukan di lapangan kelemahan SDM justru merupakan alasan utama yang sebenarnya bertanggung jawab atas besarnya di silpa di sana.

\section{Bibliography}


Bahar, Ujang. 2007. "Wewenang Pemerintah Daerah terhadap Pinjaman yang Sumber Dananya Berasal dari Luar Negeri", dalam Jurnal Hukum Bisnis, Vol.26, No. 4, Tahun 2007.

Brancati, Dawn. 2009. Peace by Design: Managing Intrastate Conflict through Decentralization. New York: Oxford University Press.

Diamond, Larry Diamond. 2004. "Why Decentralize Power in A Democracy?," Paper dipresentasikan dalam The Conference on Fiscal and Administrative Decentralization, Baghdad. February 12, 2004.

Koswara, E. 2001. Otonomi Daerah untuk Demokrasi dan Kemandirian Rakyat. Jakarta: Yayasan Pariba.

Litvack, Jennie, Junaid Ahmad, dan Richard Bird. 1998. Rethinking Decentralization in Developing Countries. Washington: World Bank.

Litvack, Jennie dan Jessica Seddon. 1998. Decentralization Briefing Notes, World Bank Institite Working Papers, World Bank dan PREM Network.

Manor, James. 1999. The Political Economy of Democratic Decentralization. Washington DC: The World Bank.

O’Neil, Kathleen. 2005. Decentralizing the State. London: Cambridge University Press.

Data Lifting Minyak dan Gas Bumi Kaltim 2013, Dinas Pertambangan Kaltim, 2013.

Hadiz, Vedi R. 2004. Decentralization and Democrazy in Indonesia: A Critique of Neo-Institutionalist Perspectives. Development and Change 35 (4): 697718.

Hoessein, Bhenyamin. 2011. Perubahan Model, Pola, dan Bentuk Pemerintahan Daerah: dari Era Orde Baru ke Era Reformasi. Jakarta: Departemen Ilmu Administrasi FISIP UI.

O’Neill, Kathleen. 2005. Decentralizing the State: Elections, Parties, and Local Power in the Andes. New York: Cambridge University Press.

Riggs, Fred W. 1969. "The Structure of Government and Administrative Reform" in Ralp Braibanti, et.all., Political and Administrative Development. Durham, N.C.: Duke University Press.

Shah, Anwar dan Sana Shah. 2006. "The New Vision of Local Governance and the Evolving Roles of Local Governments," dalam Anwar Shah (Ed.) Local Governance in Developing Countries, Washington: The World Bank. 
Tryatmoko, Mardyanto Wahyu. 2013. "Problem Demokratisasi dalam Desentralisasi Asimetris Pasca Orde Baru", naskah belum terbit. http://diskominfo.kaltimprov.go.id, 30 Oktober 2012.

http://www.scribd.com, 20 Agustus 2010.

http://hizbut-tahrir.or.id/12 Desember 2012,

http://www.portalkbr.com, 26 Desember 2012

http://tantocenter.blogspot.com/ Sunday, June 1, 2008,

http://www.kaltimpost.co.id, 23 Oktober 2012,

http://www.samarindatepian.com, 21 October, 2012,

http://www.merdeka.com, 26 november 2012,

http://diskominfo.kaltimprov.go.id, 30 Oktober 2012

http://www.antarakaltim.com, 29 Oktober 2012, 